\title{
Mount St. Helens — From the 1980 Eruption to 2000
}

ount St. Helens, Washington, is
the most active volcano in the
Cascade Range. Its most recent series
of eruptions began in 1980 when a large
landslide and powerful explosive
eruption created a large crater, and
ended 6 years later after more than a
dozen extrusions of lava built a dome in
the crater. Larger, longer lasting
eruptions have occurred in the
volcano's past and are likely to occur in
the future. Although the volcano seems
to have returned to a period of quiet,
scientists with the U.S. Geological
Survey and University of Washington
Geophysics Program continue to closely
monitor Mount St. Helens for signs of
renewed activity.

\section{The Volcano Awakens}

\section{March 16 - May 17, 1980}

The first sign of activity at Mount St. Helens in the spring of 1980 was a series of small earthquakes that began on March 16. After hundreds of additional earthquakes, steam explosions on March 27 blasted a crater through the volcano's summit ice cap. Within a week the crater had grown to about 1,300 feet in diameter and two giant crack systems crossed the entire summit area. By May 17, more than 10,000 earthquakes had shaken the volcano and the north flank had grown outward at least 450 feet to form a noticeable bulge. Such dramatic deformation of the volcano was strong evidence that molten rock (magma) had risen high into the volcano.

\section{Cataclysmic Eruption}

\section{May 18, 1980}

Within 15 to 20 seconds of a magnitude 5.1 earthquake at 8:32 a.m., the volcano's bulge and summit slid away in a huge landslide the largest on Earth in recorded history. The landslide depressurized the volcano's magma system, triggering powerful explosions that ripped through the sliding debris. Rocks, ash, volcanic gas, and steam were blasted upward and outward to the north. This lateral blast of hot material accelerated to at least 300 miles per hour, then slowed as the rocks and ash fell

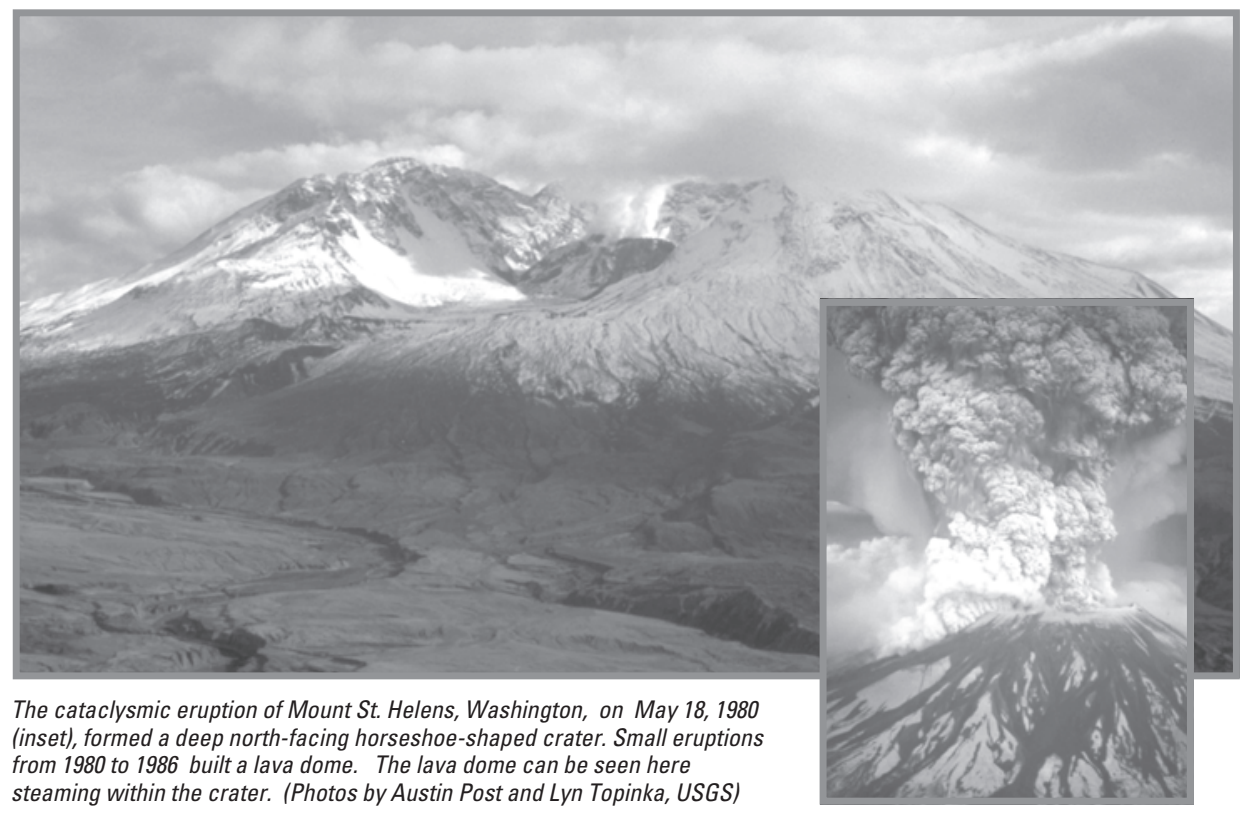

to the ground and spread away from the volcano; several people escaping the blast on its western edge were able to keep ahead of the advancing cloud by driving 65 to 100 miles an hour! The blast cloud traveled as far as 17 miles northward from the volcano and the landslide traveled about 14 miles west down the North Fork Toutle River.

The lateral blast produced a column of ash and gas (eruption column) that rose more than 15 miles into the atmosphere in only 15 minutes. Less than an hour later, a second eruption column formed as magma erupted explosively from the new crater. Then, beginning just after noon, swift avalanches of hot ash, pumice, and gas (pyroclastic flows) poured out of the crater at 50 to 80 miles per hour and spread as far as 5 miles to the north. Based on the eruption rate of these pyroclastic flows, scientists estimate that the eruption reached its peak between 3:00 and 5:00 p.m. Over the course of the day, prevailing winds blew 520 million tons of ash eastward across the United States and caused complete darkness in Spokane, Washington, 250 miles from the volcano.

During the first few minutes of this eruption, parts of the blast cloud surged over the newly formed crater rim and down the west, south, and east sides of the volcano. The hot rocks and gas quickly melted some of the snow and ice capping the volcano, creating surges of water that eroded and mixed with loose rock debris to form volcanic mudflows (lahars). Several lahars poured down the volcano into river valleys, ripping trees from their roots and destroying roads and bridges.

The largest and most destructive lahar was formed by water seeping from inside the huge landslide deposit through most of the day. This sustained flow of water eroded material from both the landslide deposit and channel of the North Fork Toutle River. The lahar increased in size as it traveled downstream, destroying bridges and homes and eventually flowing into the Cowlitz River. It reached its maximum size at about midnight in the Cowlitz River about 50 miles downstream from the volcano.

\section{Explosions and Dome Growth}

\section{May 25-October 16, 1980}

Five smaller explosive episodes occurred during the summer and fall of 1980. Each produced eruption columns 8 to 9 miles above sea level and pyroclastic flows down the volcano's north flank. The episodes in June, August, and October also erupted lava in the crater to form a dome. Lava domes are moundshaped features that form when stiff, viscous lava accumulates over and around a volcanic vent. The June and August domes were destroyed by subsequent explosive episodes. 


\section{Summary of May 18, 1980 Eruption of Mount St. Helens}

\section{Volcano}

Elevation of summit

Volume removed*

Crater dimensions

Crater floor elevation

Landslide

Area and volume*

Depth of deposit

Velocity

\section{Lateral Blast}

Area covered

Volume of deposit*

Depth of deposit

Velocity

Temperature

Energy released

Trees blown down

\section{Lahars}

Velocity

Damaged

Effects on Cowlitz

River

Effects on Columbia

River
9,677 feet before; 8,363 feet after; 1,314 feet removed

0.67 cubic miles ( 3.7 billion cubic yards)

1.2 miles (east-west); 1.8 miles (north-south); 2,084 feet deep

6,279 feet

23 square miles; 0.67 cubic miles ( 3.7 billion cubic yards)

Buried 14 miles of North Fork Toutle River Valley to an average depth of 150 feet (max. depth 600 feet)

70 to 150 miles per hour

230 square miles; reached 17 miles northwest of the crater

0.046 cubic miles ( 250 million cubic yards)

From about 3 feet at volcano to less than 1 inch at blast edge

At least 300 miles per hour

As high as $660^{\circ} \mathrm{F}\left(350^{\circ} \mathrm{C}\right)$

24 megatons thermal energy ( 7 by blast, rest through release of heat)

4 billion board feet of timber (enough to build about 300,000 two-bedroom homes)

Eruption Column and Cloud

Height

Downwind extent

Volume of ash*

Ash fall area

Ash fall depth

\section{Pyroclastic Flows}

Area covered

Volume \& depth*

Velocity

Temperature

Fatalities

Human

Wildlife

About 10 to 25 miles per hour (over 50 miles per hour on steep flanks of volcano)

27 bridges, nearly 200 homes

Reduced carrying capacity at flood stage at Castle Rock from 76,000 cfs (cubic feet per second) to less than $15,000 \mathrm{cfs}$

Reduced channel depth from 40 to 14 feet; stranded 31 ships in upstream ports

Reached about 80,000 feet in less than 15 minutes

Spread across US in 3 days; circled Earth in 15 days

0.26 cubic miles (1.4 billion cubic yards)

Detectable amounts of ash covered 22,000 square miles

10 inches at 10 miles downwind (ash and pumice); 1 inch at 60 miles downwind; $1 / 2$ inch at 300 miles downwind

6 square miles; reached as far as 5 miles north of crater

0.029 cubic miles ( 155 million cubic yards); multiple flows 3 to 30 feet

thick; cumulative depth of deposits reached 120 feet in places

Estimated at 50 to 80 miles per hour

At least $1,300^{\circ} \mathrm{F}\left(700^{\circ} \mathrm{C}\right)$

57

Countless non-burrowing wildlife in blast area, including about 7,000 big

game animals; about 12 million salmon fingerlings in hatcheries.

* Volumes are based on uncompacted deposits

\section{October 16, 1980 - October 21, 1986}

Beginning with the October 1980 eruption, 17 eruptive episodes built a new lava dome that reached 876 feet above the crater floor. Minor explosive activity and (or) lahars accompanied several of the 1981 to 1986 episodes. Each of the dome-building episodes added between 1 and 29 million cubic yards of new lava to the dome. Most of the growth occurred when magma extruded onto the surface of the dome, forming short (650 to 1,300 feet), thick ( 65 to 130 feet) lava flows. During a 12-month-long episode beginning in 1983, however, magma moved primarily into the dome's molten interior, pushing its east side outward by at least 250 feet. In addition to the 17 dome-building episodes, hundreds of small explosions or bursts of gas and steam occurred, sending ash a few hundred feet to several miles above the volcano. The larger explosions showered the crater with rocks and occasionally generated small lahars.

\section{November 1986 - December 1999}

Since late 1986 several periods of increased seismicity have occurred. Between 1989 and 1991 there were about 30 bursts of brief but intense seismic activity lasting minutes to hours. Several of these bursts were accompanied by small explosions from the dome. The explosions formed a new vent on the north side of the dome and produced small eruption columns that rose a few miles above the volcano. A few explosions also hurled hot rocks three feet in diameter at least $1 / 2$ mile northward from the dome, generated small pyroclastic flows in the crater, and formed small lahars. During 1995 and 1998 seismicity increased for several months, but there were no accompanying explosions.
Magmatic Eruptions Since May 18, 1980

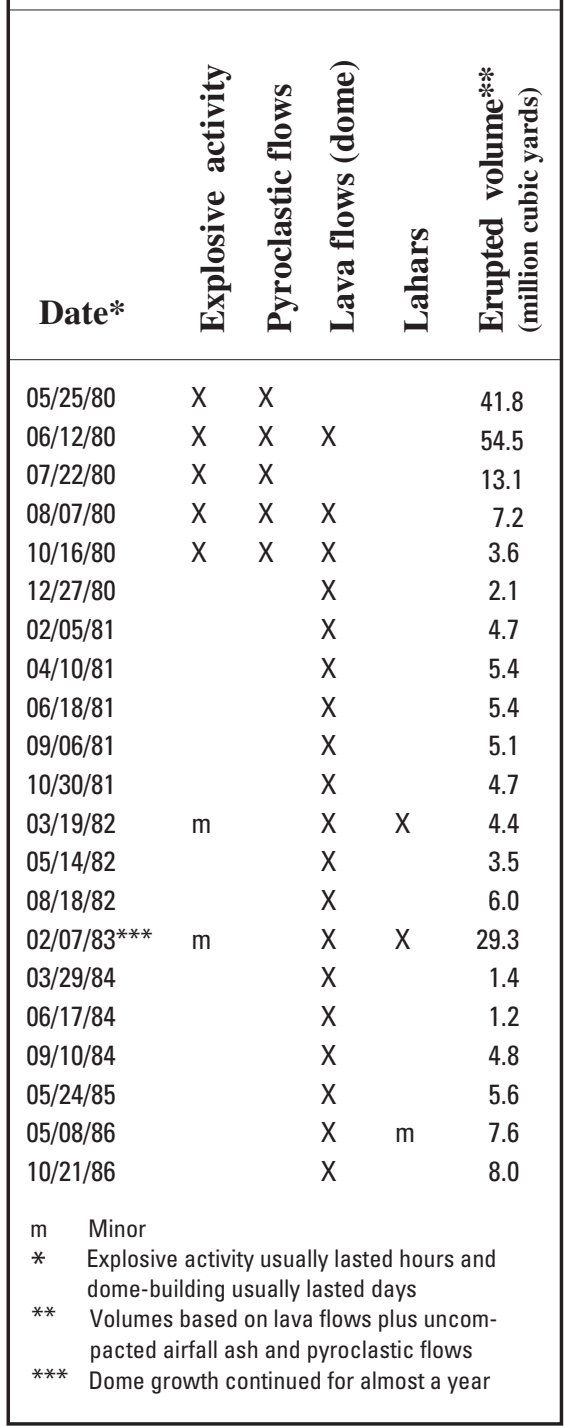

\section{Lava Dome Dimensions}

Elevation of top of dome: 7,155 feet Height: 876 feet above 1980 crater floor Diameter: About 3,500 feet

Volume: 97 million cubic yards

Steven R. Brantley and Bobbie Myers

COOPERATING ORGANIZATIONS

U.S. Dept. of Agriculture, Forest Service University of Washington, Geophysics Program

For more information contact:
U.S. Geological Survey
Cascades Volcano Observatory
5400 MacArthur Blvd., Vancouver, WA 98661
Tel: (360) 993-8900, Fax: (360) 993-8980
http://vulcan.wr.usgs.gov/
or
USGS Volcano Hazards Program
http://volcanoes.usgs.gov/
the 1980 Eruption to 1996
(USGS Fact Sheet 070-97)
See also What are Volcano Hazards?
(USGS Fact Sheet 002-97)

